В. Загрійчук. Рекреаційна оцінка рельєфу...

УДК 551.4; DOI 10.30970/GPC.2019.1.2809

РЕКРЕАЦІЙНА ОЦІНКА РЕЛЬЕФУ ДНІСТРОВСЬКОГО

РЕГІОНАЛЬНОГО ЛАНДШАФТНОГО ПАРКУ

(ІВАНО-ФРАНКІВСЬКА ОБЛАСТЬ)

Володимир Загрійчук

Львівський національний університет імені Івана Франка, vzagriychuk93@gmail.com

Анотація. Охарактеризовано адміністративно-господарську структуру території Дністровського регіонального ландшафтного парку, створеного у 1993 року, що займає площу 19556 га і розташований уздовж русла р. Дністер у межах Городенківського й Тлумацького районів Івано-Франківської області. Проаналізовано літературні і фондові матеріали щодо геологічної будови й геоморфологічних особливостей території розташування Дністровського РЛП та подано головні риси його рельєфу Парк розташований у межах шести геоморфологічних підрайонів, об'єднаних двома геоморфологічними районами: Опільської структурно-денудаційної увалистої, сильнорозчленованої височини та Північнопокутської структурно-денудаційної полого-хвилястої височини Подільської структурно-денудаційної височинної геоморфологічної підобласті. На основі опрацювання праць дослідників зазначеної території подано короткий опис кожного із підрайонів. 3 використанням функціональних можливостей програми ArcGis 10.2, шляхом оцифрування топографічних карт масштабу 1:50 000, укладено тривимірну модель рельєфу та серію морфометричних карт (вертикального і горизонтального розчленування рельєфу, крутості земної поверхні, експозиції схилів), за якими охарактеризовано особливості рельєфу природоохоронної установи. Використовуючи методику функціональноморфометричної оцінки рельєфу болгарського вченого Х. Тішкова (1984), яка адаптована П. Горішним, Ю. Зіньком і М. Кобелькою для височинного рельєфу території України, здійснено функціональну рекреаційну оцінку рельєфу РЛП на рівні геоморфологічних підрайонів i виокремлено ділянки, сприятливі для розвитку різних видів рекреаційних занять. Згідно з методикою, для кожного виду оцінок присвоєно бальну шкалу на основі значень морфометричних показників. Отримані бали внесено до зведеної таблиці та за переважанням балів, визначено придатність території для відповідного виду рекреаційної діяльності. За результатами оцінювання визначено, що Бистрицько-Тлумацький i Олешанський підрайони найбільше сприятливі для розвитку спортивного туризму, Городенківський - для прогулянкової рекреації, а Бурштинський, Дністерський та Чернелицький підрайони - для відпочинкової.

Ключові слова: Дністровський РЛП; морфометричні карти; рекреаційна оцінка рельєфу; спортивно-туристична, прогулянкова і відпочинкова рекреація.

\title{
RECREATIONAL RELIEF ASSESSMENT OF THE DNISTROVSKYI REGIONAL LANDSCAPE PARK (IVANO-FRANKIVSK REGION)
}

Volodymyr Zahriichuk, Ivan Franko National University of Lviv

(C) Загрійчук Володимир, 2019. 


\begin{abstract}
The administrative and economic structure of the territory of the Dnistrovskyi Regional Landscape Park (19,556 ha, 1993), located along the channel of the Dniestr river in the limits of Gorodenkivsky and Tlumatsky districts of Ivano-Frankivsk region, has been characterized. The literature and stock materials concerning geological structure and geomorphological features of the territory of the Dniester RLP were analyzed and the main features of its relief were presented. The park is located within the limits of six geomorphological sub-districts, united by two geomorphological regions: the Opil Structural-Deductive Wavy, the Highly Dissociated Heights, and the North Pokutsk Structural-Denductive Hollow-Wavy Heights of the Podolian structural-denudational highrise geomorphological sub-districts. Using the ArcGis 10.2 functionality, based on the digitization of 1:50 000 topographic maps, a 3D model of relief and a series of morphometric maps (vertical and horizontal dismemberment of the terrain, the steepness of the earth's surface, exposure of the slopes) are made, which describes the peculiarities of the relief of the nature conservation institution. Using the method of functionalmorphometric assessment of the relief of the Bulgarian scientist H. Tishkov (1984), a functional recreational assessment of the RLP relief was carried out at the level of the geomorphological sub-regions and the areas designated for the development of various types of recreational activities were identified. The points obtained are included in the summary table, and the predominance of points determines the suitability of the territory for the respective type of recreational activity. According to the results of the evaluation, it is determined that the Bystritsko-Tlumatsky and Oleshansky subareas are most favorable for the development of sports tourism, Gorodenkivskyi - for leisure recreation and Burshtynskyi, Dnistersky and Chernelitsky subareas - for recreation.
\end{abstract}

Key words: Dnistrovskyi RLP; morphometric maps; recreational relief assessment; sports and tourist, walking and recreation.

Вступ. Дністровський регіональний ландшафтний парк (РЛП) імені Сергія Дідича створено 1993 року з метою збереження унікальних природних комплексів уздовж ріки Дністер у межах Івано-Франківської області. Парк має статус природоохоронної установи місцевого значення і розташований на території Городенківського й Тлумацького районів, охоплюючи землі однієї селищної та 21-ї сільської ради, у межах яких розташовано 48 населених пунктів (Звіт, 2012).

Природоохоронний об'єкт має такі основні завдання: 1) збереження цінних природних та історико-культурних комплексів та об'єктів; 2) створення умов для ефективного туризму, відпочинку та інших видів рекреаційної діяльності в природних умовах; 3) сприяння екологічній освітньо-виховній роботі; 4) підтримання загального екологічного балансу в регіоні (Звіт, 2012).

Ефективній рекреаційній діяльності сприяють природні чинники, серед яких головними є кліматичні умови, що визначають тривалість періоду комфортного відпочинку та рекреаційні властивості рельєфу для різних видів активної рекреації. У зв'язку з цим, важливим є з'ясування можливості використання ділянок РЛП 3 різними типами рельєфу для певних видів рекреації. Власне морфометричні характеристики рельєфу впливають на придатність окремих територій для різних видів рекреації і туризму. Однією із важливих характеристик рельєфу є його естетичне сприйняття завдяки поєднанню морфологічних ознак. Дослідження 
питань естетики рельєфу у наш час має помітний розвиток (Горішний, 1998; Зінько, 2003; Звіт, 2012).

Також властивості рельєфу відіграють значну роль у проектуванні природоохоронних об’єктів та територій (Карпенко, 2002; Бердихин, 2010; Pereira, Pereira, 2010; Serrano, Gonzalez-Trueba, 2005).

Наша мета - з'ясувати придатність якісно відмінних ділянок Дністровського РЛП для певних видів рекреаційної діяльності. Об'єкm дослідження морфометричні характеристики рельєфу у межах Дністровського РЛП та його генетична різноманітність, а предмет - рекреаційні властивості рельєфу та його потенційна зумовленість певним видам рекреаційної діяльності.

Методика і методи дослідження. У дослідженні для рекреаційної оцінки рельєфу використано методику болгарського вченого Х. Тішкова (1984), яку П. Горішним, Ю. Зіньком і М. Кобелькою (1994) адаптовано для височини Розточчя (Горішний, Зінько і Кобелька, 1994; Тишков, 1984). Методика базується на використанні серії морфометричних карт певної території, отож важливо створити карти $з$ дотриманням картографічних вимог. Серед морфометричних карт найширше застосування мають карти: крутості земної поверхні; горизонтального i вертикального розчленування рельєфу (Загрійчук, 2016; Кравчук, 2006; Байрак, 2010). Зазначені морфометричні карти складено 3 використанням програми ESRI ArcGIS Desktop 10.2. на основі топокарт масштабу 1:50 000 (Андрейчук i Ямелинець, 2015; Загрійчук, 2016; Байрак, 2008). Значення величин крутості земної поверхні використано за класифікацією Брауде, яку наведено у праці Я. Кравчука (Кравчук, 2006).

Згідно 3 методикою рекреаційної оцінки рельєфу Х. Тішкова, необхідно виокремити певні однорідні ділянки території дослідження, які оцінюватимуть. Такими ділянками обрано геоморфологічні підрайони у межах Дністровського РЛП (Загрійчук, 2018; Тішков, 1984).

Рельєф і геоморфологічне районування території досліджень. За сучасним геоморфологічним районуванням (Національний.., 2007) Дністровський РЛП розташований у Подільській структурно-денудаиійній височинній підобласті Волино-Подільської області. Досліджувана територія охоплює два геоморфологічні райони: Опільської структурно-денудаційної увалистої, сильнорозчленованої височини та Північнопокутської структурно-денудаційної полого-хвилястої височини (Геренчук,1973).

У межах цих районів услід за Я. Кравчуком і Ю. Зіньком (1989), можна виокремити шість геоморфологічних підрайонів на підставі відмінностей морфометричних показників рельєфу. Дністровський РЛП охоплює ділянки п’яти підрайонів: Бурштинської, Бистрицько-Тлумацької, Олешанської, Чернелицької та Городенківської височин, а також, окремим підрайоном можна вважати розширену частину долини Дністра із заплавою і низькими терасами, що обмежені крутими уступами (Атлас..,1989).

Бурштинська височина є частиною Опілля, яке розкинулося на лівобережжі Дністра (Геренчук,1973) та заходить на територію Дністровського РЛП своїм південним краєм. Із заходу та півдня височина обмежена руслом Дністра, а на сході - річкою Коропець. Височина характеризується середніми висотами понад 300 м. Проте у межах парку вони сягають 250-280 м, лише на межиріччі Золотої Липи та Коропця відмітки абсолютних висот сягають 300-320 м (Геренчук, 1973). 
В. Загрійчук. Рекреаційна оцінка рельєфу...

Бистрицько-Тлумацька височина займає західну частину Покуття між ріками Тлумач і Бистриця. Південна межа проходить річками Хрус і Дустрів. У межах парку височина охоплює межиріччя Дністра - Тлумача. Підрайон вирізняється значними абсолютними висотами (320-350 м) і глибоким розчленуванням (100150 м/км²), передусім уздовж долини Дністра. Найвищою точкою є г. Скеля $(349,2)$ на правобережжі Тлумача (Геренчук, 1973).

Олешанська височина розміщена між ріками Тлумач та Гостилів. Північну межу проводять долиною Дністра саме в тій частині, де розташовані великі меандри: Гориглядівська, Делівська, Петрівська та Луківська. Південна межа - невиразна, простягається уздовж широкого зниження у рельєфі між Тлумачем і Хотимиром. Тут К. І. Геренчук (1973) виокремлює Хотилир-Чортовецьке пониження, яке можна вважати окремим мезорегіоном. Абсолютні висоти в підрайоні сягають 350-350 м. Найвищою точкою є гора Глинка $(351,3)$ поблизу с. Живачів. Для цієї височини характерне незначне розчленування рельєфу, інтенсивність якого збільшується 3 наближенням до Дністра. Рівнинний рельєф та наявність сульфатних і карбонатних порід зумовлюють розвиток на привододільних ділянках карстово-суфозійних процесів (Геренчук, 1973).

Чернелицька височина є слабо розчленованим плосковершинним пасмом, що знаходиться на півночі Городенківського району. Височина характеризується незначною розчленованістю, простягаючись 3 північного заходу на південний схід. Із заходу, півночі та сходу височина обмежена річкою Дністер. Південна та південно-західна межа - нечітка, іiї проводять зниженням уздовж лінії Хотимир Городенка. Це зниження успадковує тектонічний розлом, який простягається через досліджуваний регіон. Абсолютні середні висоти становлять 330-360 м. Тут знаходяться найвищі у рельєфі точки парку, зокрема, безіменна вершина з відміткою 393 м. Височина складена алювіальними відкладами п'ятої і шостої надзаплавних терас Дністра (Геренчук, 1973).

Городенківська височина є продовженням Хотимир-Чортовецького зниження, на чому наголошує К. І. Геренчук, має слаборозчленовану нахилену хвилясту рівнинну поверхню та характеризується дещо нижчими у межах РЛП абсолютними висотами - 280-300 м. В основі території залягають алювіальні відклади давніх терас Дністра. На території височини знаходиться багато карстових озер та їхніх заторфованих улоговин (Геренчук, 1973).

Розиирена частина каньйоноподібної долини Дністра завширшки до 3 км чітко проявляється у північній частині Тлумацького району і простягається на 16 км 3 північного заходу на південний схід. Уздовж русла річки поширені заплава та ерозійно-акумулятивні тераси, а також стрімкі схили-стінки. Чітко виражена асиметрія долини: вузьке обривисте правобережжя i широке виположене лівобережжя. Русло активно меандрує, утворюючи звивини. У днищі долини простежуються старорічища, частково пересохлі i виражені заболоченими пониженнями. Внаслідок інтенсивної глибинної і бокової ерозії простежується підмив берегів і утворення ерозійних уступів заввишки 1-1,5 м між руслом та заплавою. 3 півночі долина обмежена пологими схилами Бурштинської височини, 3 півдня - крутими уступами Бистрицько-Тлумацької та Олешанської височин. Південніше с. Нижнів спостерігається значне звуження долини, що засвідчує східну межу геоморфологічного підрайону. Для лаконічності і простоти назвемо цей підрайон Дністерським. 
На всій височинній території Дністровського РЛП переважають висоти 280320 м. Найвищою є південно-східна частина регіону з висотами 340-380 м 3 найвищою безіменною вершиною (393 м), північно-східніше села Кунисівці у межах Чернелицької височини. Найнижчі висоти - 160-180 м - поширені у межах днища долини Дністра.

Результати дослідження. Найважливішою характеристикою рельєфу, що визначає розвиток рекреаційної діяльності, є крутість земної поверхні. Середні іï значення у межах парку становлять $8-10^{\circ}$ (рис. 1). Найкрутішими $\left(35-60^{\circ}\right) \epsilon$ прямовисні стінки у межах каньйону долини Дністра. Проте переважають туг довгі відносно кругі $\left(17-35^{\circ}\right)$ ділянки, поширені на протилежних від крутих уступів берегах, які сформувались унаслідок відступання русла до протилежного берега.

На лівобережжі РЛП у межах Бурштинської височини поширені рівні $\left(0-1^{\circ}\right)$ i похилі $\left(1-3^{\circ}\right)$ схили, останні $є$ домінуючими. У межиріччі Золотої Липи - Коропця кругість збільшується до $15^{\circ}$.

У межах Олешанської височини на території парку переважають схили кругістю 3-8․ На плоских вододільних поверхнях крутість мінімальна $-1-2^{\circ}$. У місцях, де схил переходить у стінку каньйону, кругість сягає понад $60^{\circ}$. Між вирівняними вододілами i обривистими прямовисними схилами у рельєфі поширені кругі $\left(15-25^{\circ}\right)$ i сильноспадисті $\left(12-15^{\circ}\right)$ схили.

Бистрицько-Тлумацька височина, яка східним краєм заходить на територію парку, також характеризується пануванням крутих схилів. Туг переважають кругі i сильноспадисті схили, зрідка трапляються прямовисні схили на стінках каньйону Дністра.

Північний край Городенківської височини закінчується мальовничими стінками у місці, де Дністер угворює Луківську меандру. Переважають у межах РЛП спадисті (5-8) схили.

На вододільних ділянках парку у межах Чернелицької височини кругість поверхні коливається в межах 1-3․ На прилеглих територіях домінують похилі і слабоспадисті схили. Вздовж Дністра, як і у кожному із попередніх геоморфологічних підрайонів, домінують стрімкі схили. Стінки каньйону досягають крутості понад $60^{\circ}$.

Дністерський геоморфологічний підрайон суттєво відрізняється від попередніх. Тут днище долини широке і плоске, з меандруючим руслом, переважають плоскі ділянки кругістю до $1^{\circ}$. На півночі спостерігаються кругіші (до $8^{\circ}$ ) схили.

Важливою характеристикою рельєфу, що впливає на розвиток певних видів рекреаційних занять, є експозиіл схилів. У межах парку залежно від напряму руху течії Дністра і його приток, у рельєфі переважають схили північної та північно-східної експозиції.

Значна частина території дослідження є рівнинною, оскільки туг поширені вододіли i днища долин річок, зокрема Дністра (рис. 2). Зазначимо, що території, близько розташовані до долини Дністра, порізані дрібними річками, перпендикулярними до русла головної річки. Отож дрібні річки трансформують домінуючі експозиції відповідно до свого простягання.

У межах Бурштинського підрайону тотально домінують схили південної та південнозахідної експозиції. У межах Бистрицько-Тлумацького підрайону спостерігається візуальна рівність північно-східних та південно-західних схилів, субдомінують схили південно-східних експозицій. 


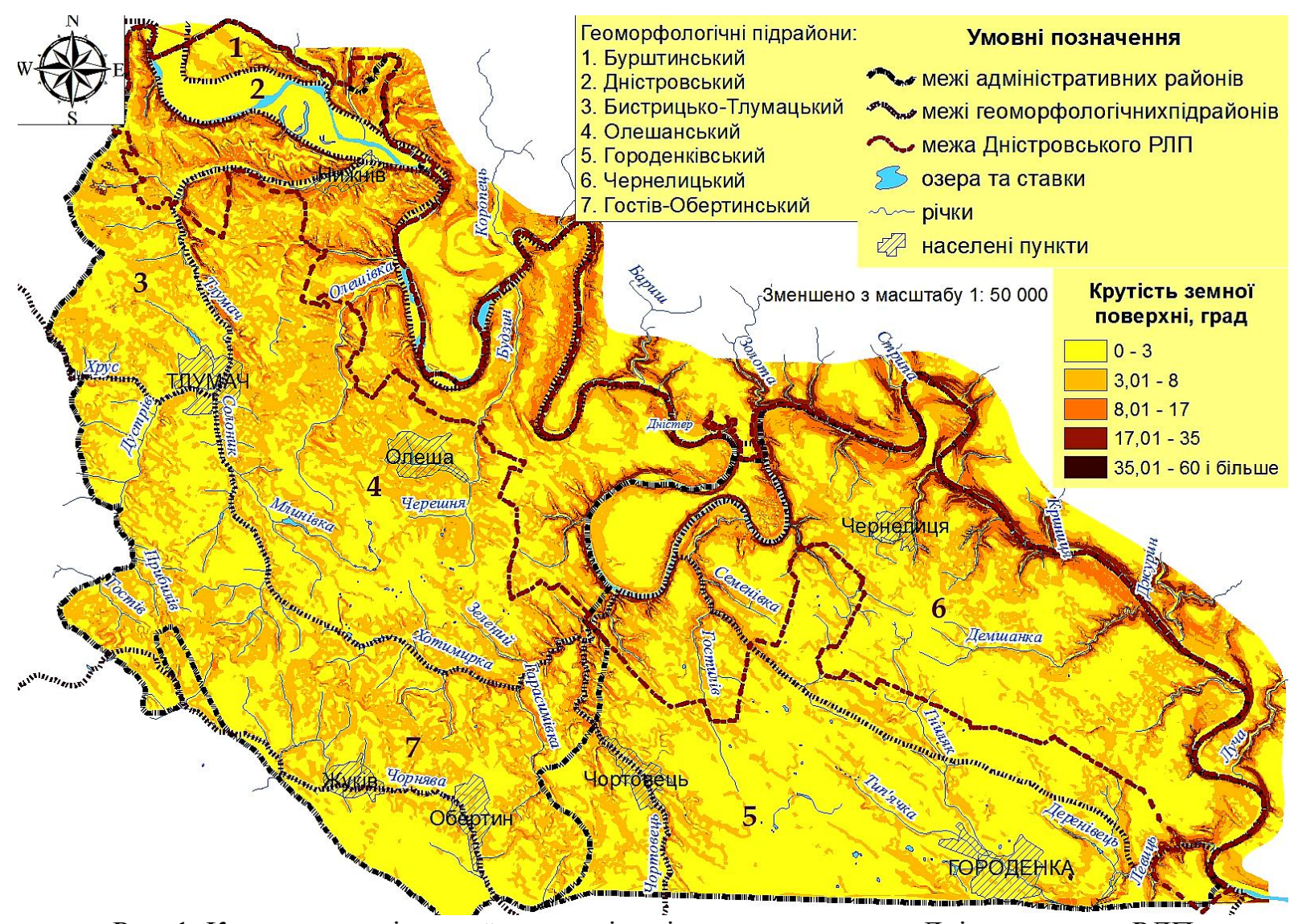

Рис. 1. Карта крутості земної поверхні регіону розташування Дністровського РЛП Fig. 1. Map of the terrestrial surface of the region of the location of the Dnistrovskyi RLP 
Експозицію схилів Олешанського підрайону визначає простягання річок Тлумач, Олешівка та Дністер. Регіон межує із меандрами Дністра, тому експозиції діаметрально змінюються. Проте домінуючими є східний і північний напрям схилів.

Чернелицький підрайон по довжині обмежується Дністровським каньйоном, який формує панівну експозицію схилів - північну. Також значну частку території займають схили зі східним напрямом. Меншу площу займають південні схили зі східними i західними субнапрямами.

Горбистість рельєфу Городенківського підрайону сприяє поширенню тут усіх можливих експозицій із незначним переважанням північного напряму.

Завдяки плоскорівнинності заплави і першої надзаплавної тераси у межах долини Дністра у Дністровському підрайоні домінують рівні ділянки без чітко виражених експозицій, а каньйоноподібні стінки сприяють домінуванню схилів північної експозиції.

Важливим морфометричним показником є горизонтальне розчленування рельєфу, який відображає щільність ерозійно-річкової мережі (його виражають у км/км²).

Загалом у межах парку значення горизонтального розчленування зростають 3 наближенням до долини Дністра. Туг частіше трапляються долини коротких річок, які глибоко врізані у межиріччя. На придолинних схилах Дністра є велика кількість зростаючих і задернованих ярів, які місцями мають вигляд невеликих каньйонів (рис. 3). Туг спостерігаються максимальні значення горизонтального розчленування рельєфу, які сягають понад 6 км/км².

Найменш розчленованим $є$ рельєф Бурштинської височини, де переважають значення $0,5-1,5$ км/км². Лише межиріччя Золотої Липи - Левця $\epsilon$ розчленованішим - 2,0$2,1 \mathrm{KM} / \mathrm{KM}^{2}$.

У межах Бистрицько-Тлумацького геоморфологічного підрайону рельєф дуже розчленований і має найвищі значення горизонтального розчленування на всій території дослідження. Вузькість межиріч і значна кругість схилів, а також обмеження їх із двох протилежних боків річками сприяють розвитку лінійної ерозії. Численні яри та балки, які розчленовують схили височини визначають максимальні значення розчленування $5,5 \mathrm{\kappa м} / \mathrm{\kappa м}^{2} \mathrm{i}$ більше.

Також сильно розчленованими $є$ схили Дністровського каньйону поблизу смт Черенлиця $(4,4-5,0$ км/км²) у межах однойменного геоморфологічного підрайону. Численні малі річки та тимчасові водотоки, які несугь свої води у Дністер, спричиняють активний розвиток ерозійних процесів. Яри, балки та інші лінійні пониження формують максимальні значення горизонтального розчленування уздовж гідромережі. Водночас привододільні ділянки мають низькі значення розчленування $-0,5-1,1$ км/км².

Олешанська височина сильно розчленована лише у північній частині, де у Дністер впадають річки Тлумач і Олешівка. Значення горизонтального розчленування на схилах їхніх басейнів коливаються від 4,0 до 5,0 км/км², а у південній частині височини зменшуються до $3,2-3,3$ км/км². Мінімальні значення спостерігаються у центральній частині Луківської меандри - менше 0,5 км/км².

Північний край Городенківської височини також сильно розчленований. На ділянці, де тече р. Гарасимівка, значення розчленування сягають 2,0-3,0 км/км², проте домінують значення $1,5-2,0$ км/км². 


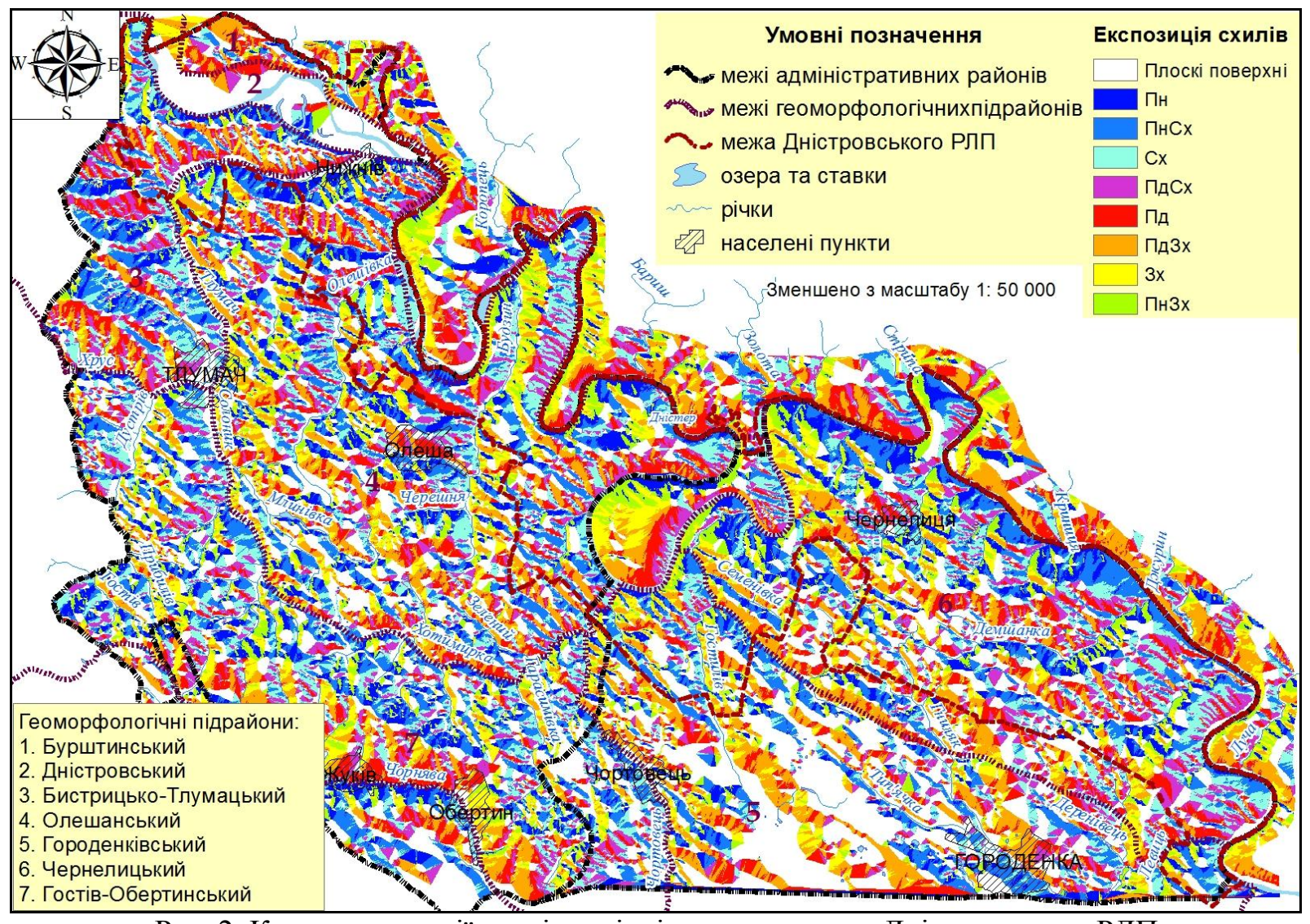

Рис. 2. Карта експозиції схилів регіоніу розташування Дністровського РЛП

Fig. 2. Exposure map of the slopes of the region in the location of the Dnistrovskyi RLP 
Широка каньйоноподібна долина Дністра слабо розчленована $-0,5-1,2$ км/км². Обривисті і прямовисні схили-стінки не сприяють розвитку лінійної ерозії, як і плоска заплава $з$ першою надзаплавною терасою.

Вертикальне розчленування рельє фу відображає абсолютну величину перепаду висот у межах певної ділянки, і його визначають у метрах на квадратний кілометр.

Дністровський РЛП охоплює ділянки 3 найбільшими перевищеннями у межах двох - Опільського і Покутського - геоморфологічних районів. Максимальні значення характерні для схилів уздовж долини Дністра, де вони коливаються у межах 200-220 м/км² (рис. 4).

Найодноріднішим виглядає Бурштинський підрайон, у якому вертикальне розчленування становить $60-80 \mathrm{~m} / \mathrm{\kappa м}^{2}$. У межах Дністерського підрайону рельєф контрастніший. Перепад висот між брівками стінок каньйону і заплавою сягає $100-$ 110 м. На правобережжі долини значення зменшуються вдвічі. На території Бистрицько-Тлумацької височини переважають значення 100-150 м/км².

У межах Олешанської височини перевищення зростають. У місцях поширення каньйоноподібних стінок вони сягають максимальних значень - 160-200 м/км², а домінують значення в діапазоні від 120 до $150 \mathrm{M} / \mathrm{\kappa m}^{2}$.

Уздовж краю Городенківської височини спостерігається поступова зміна перевищень із півночі на південь. Від Дністра, де фіксуються максимальні значення (145 м/км²), на південь перевищення зменшуються до 40-75 м/км² і менше. Рельєф вирівнюється і круті схили переходять у виположені привододільні поверхні.

Найрізноманітнішим є рельєф Чернелицької височини. Тут річка Дністер формує вузьку каньйоноподібну долину вздовж усього геоморфологічного підрайону, огинаючи його з заходу, півночі та сходу. Отож уздовж Дністра спостерігаються максимальні перевищення, які сягають 200-220 м/км². У місцях впадіння приток Гостилів, Левиць та інших перевищення зменшуються до 145-200 м/км². 3 віддаленням на південь від Дністра рельєф вирівнюється, домінують привододільні поверхні, отож значення вертикального розчленування зменшуються до 40-60 м/км². Мінімальні перевищення $(0-40$ м/км² $)$ зафіксовані уздовж південної межі парку.

Завдяки отриманим за морфометричними картами морфометричним показникам для території дослідження нам вдалося поділити їх на відповідні градації та здійснити рекреаційну оцінку рельєфу у балах для кожної з його функцій, для якої прийнято свій набір оцінок і градацій. Бальна оцінка полягає у присвоєнні геоморфологічному підрайону певної спеціалізації за переважанням значень різних морфометричних показників. Краща оцінка визначалась на основі більшої суми балів оцінюваних морфометричних показників (Карпенко, Горішний, Зінько, 2005).

Для спортивно-туристичної функиї важливе значення має різноманітність рельєфу, значне його розчленування та варіативність. Присутність на території природних перешкод і різних морфологічних типів рельєфу, наявність природних скель і високих відслонень чи прямовисних стінок робить іï привабливою для тренувань і змагань із альпінізму, орієнтування на місцевості, відпрацювання техніки активного туризму. Для оцінки спортивно-туристичної функції використовують три морфометричні показники: вертикальне i горизонтальне розчленування території та крутість схилів. Присвоєння балів для цієї функції рельєфу за трьома показниками прямопропорційне зростанню їхніх значень (табл. 1). 


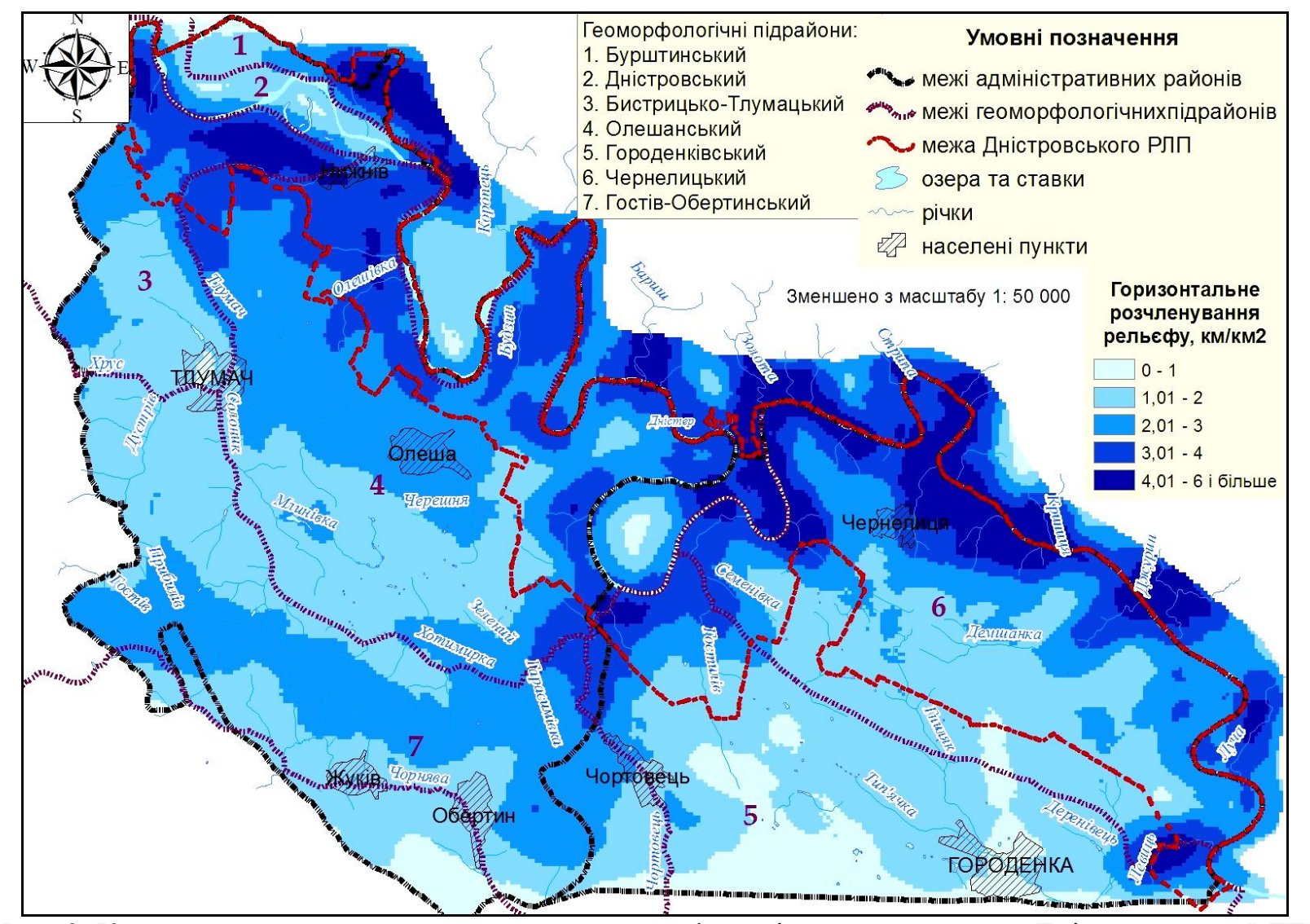

Рис. 3. Карта горизонтального розчленування рельєфу регіону розташування Дністровського РЛП

Fig. 3. Map of horizontal dismemberment of the relief region of the location of the Dnistrovskyi RLP 


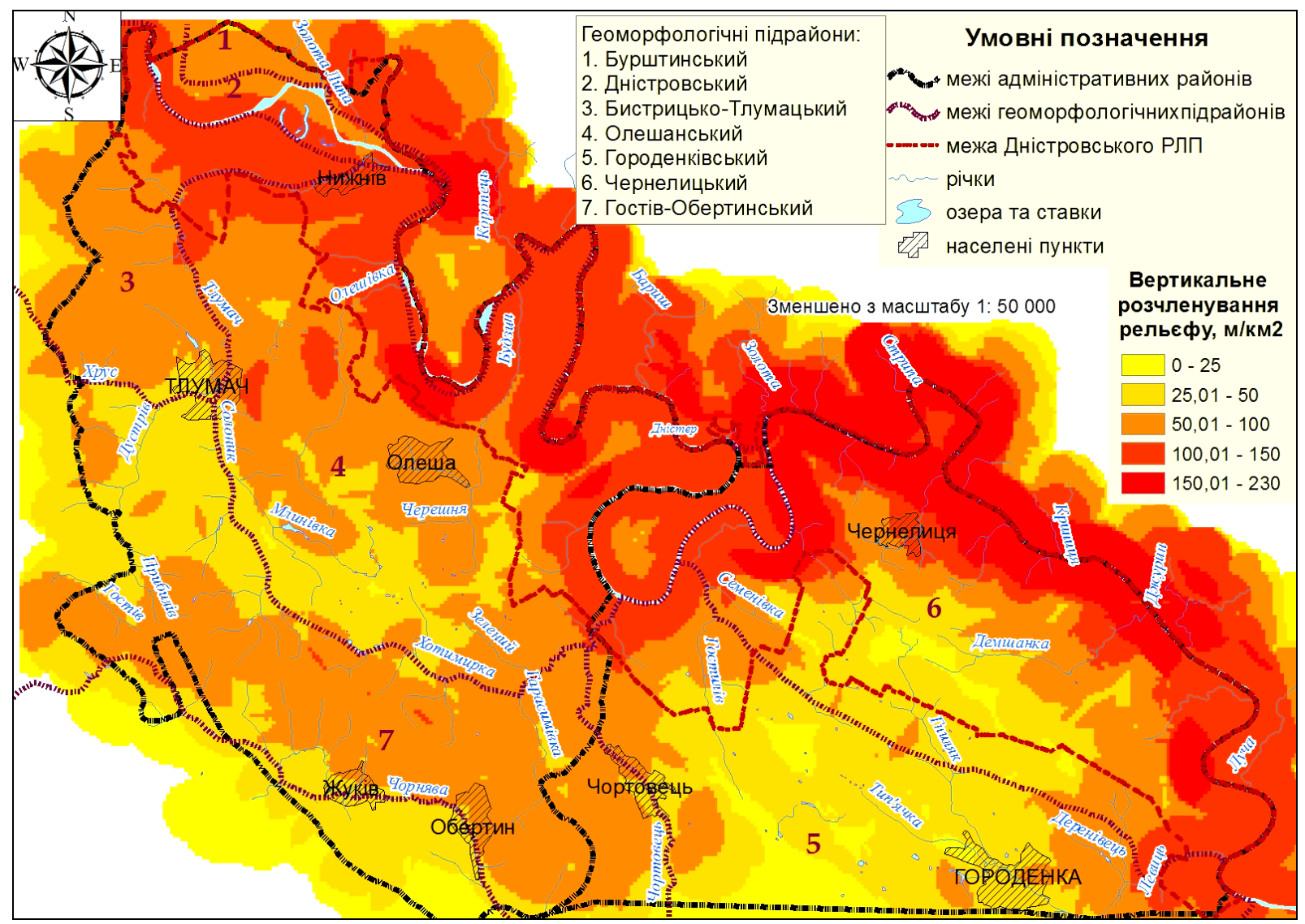

Рис. 4. Вертикальне розчленування рельєфу регіону розташування Дністровського РЛП Fig. 4. Vertical dismemberment of the relief of the region of the Dnistrovskyi RLP location 
В. Загрійчук Рекреаційна оцінка рельєфу..

ISSN 2519-2620. Проблеми геоморфології і палеогеографії... 2019. Вип. 1 (9), 166-182

Таблиця 1. Бальна оцінка спортивно-туристичної функції рельєфу

Table 1. Balance rating of the sports and tourist function of the relief

\begin{tabular}{|c|c|c|c|}
\hline \multirow{2}{*}{ Кількість балів } & \multicolumn{3}{|c|}{ Морфометричні показники } \\
\cline { 2 - 4 } & $\begin{array}{c}\text { Вертикальне } \\
\text { розчленування, } \\
\text { м/км }\end{array}$ & $\begin{array}{c}\text { Горизонтальне } \\
\text { розчленування, } \\
\text { км/км }{ }^{2}\end{array}$ & $\begin{array}{c}\text { Крутість схилів, } \\
\text { о }\end{array}$ \\
\hline 5 & Понад 150 & Понад 4 & Понад 35 \\
\hline 4 & $100-150$ & $3-4$ & $17-35$ \\
\hline 3 & $50-100$ & $2-3$ & $8-17$ \\
\hline 2 & $25-50$ & $1-2$ & $3-8$ \\
\hline 1 & $0,1-25$ & $0,1-1$ & $0,1-3$ \\
\hline
\end{tabular}

Для відпочинкової функиї території важливим $є$ рівнинність (плоскість) і мінімальне вертикальне розчленування рельєфу. Ця функція має протилежне призначення, ніж попередня, оскільки суть функції полягає у можливості рекреанта відпочити від навантажень. Також тут до уваги беруть експозицію схилів, оскільки “теплі” схили сприятливіші і комфортніші для відпочинку, ніж “холодні”. Основним напрямам сторін горизонту присвоюють ціле значення балу, а проміжним - середню оцінку між двома цілими значеннями (табл. 2).

Таблиця 2. Бальна оцінка відпочинкової функції рельєфу

Table 2. Balance rating of the recreations function of the relief

\begin{tabular}{|c|c|c|c|c|}
\hline \multirow{2}{*}{$\begin{array}{c}\text { Кількість } \\
\text { балів }\end{array}$} & $\begin{array}{c}\text { Вертикальне } \\
\text { розчленування, } \\
\text { м/км }{ }^{2}\end{array}$ & $\begin{array}{c}\text { Горизонтальне } \\
\text { розчленування, } \\
\text { км/км }{ }^{2}\end{array}$ & $\begin{array}{c}\text { Крутість } \\
\text { схилів, }\end{array}$ & $\begin{array}{c}\text { Експозиції } \\
\text { схилів }\end{array}$ \\
\hline 5 & $0,1-25$ & $0,1-1$ & $0,1-3$ & $\begin{array}{c}\text { Плоскі } \\
\text { поверхні }\end{array}$ \\
\hline 4 & $25-50$ & $1-2$ & $3-8$ & Пд \\
\hline 3 & $50-100$ & $2-3$ & $8-17$ & $3 \mathrm{x}$ \\
\hline 2 & $100-150$ & $3-4$ & $17-35$ & Сх \\
\hline 1 & Понад 150 & Понад 4 & Понад 35 & Пн \\
\hline
\end{tabular}

Прогулянкову функиію рельєфу оцінюють з бальними шкалами, які беруть за зразком загальної рекреаційної оцінки, причому визначальними є різноманітність рельєфу та сприятлива експозиція схилів. Найбільше балів отримують середні значення морфометричних показників (табл. 3).

Після детального аналізу кожного із морфометричних показників і присвоєння відповідних балів ми здійснили сумарну рекреаційну оцінку рельєфу кожного геоморфологічного підрайону та визначили для окремих ділянок РЛП їхнє потенційне функціональне призначення (табл. 4), яке відображено на підсумковій карті (рис. 5). 
В. Загрійчук Рекреаційна оцінка рельєфу..

ISSN 2519-2620. Проблеми геоморфології і палеогеографії... 2019. Вип. 1 (9), 166-182

Таблиця 3. Бальна оцінка прогулянкової функції рельєфу

Table 3. Balance rating of the relief function

\begin{tabular}{|c|c|c|c|c|}
\hline \multirow[b]{2}{*}{$\begin{array}{l}\text { Кількість } \\
\text { балів }\end{array}$} & \multicolumn{4}{|c|}{ Морфометричні показники } \\
\hline & $\begin{array}{c}\text { Вертикальне } \\
\text { розчленування, } \\
\text { м/км }\end{array}$ & $\begin{array}{c}\text { Горизонтальне } \\
\text { розчленування, } \\
\text { км/км }{ }^{2}\end{array}$ & $\begin{array}{l}\text { Кругість } \\
\text { схилів, }{ }^{\circ}\end{array}$ & $\begin{array}{c}\text { Експозиції } \\
\text { схилів }\end{array}$ \\
\hline 5 & $50-100$ & $2-3$ & $3-8$ & $\begin{array}{c}\text { Плоскі } \\
\text { поверхні }\end{array}$ \\
\hline 4 & $100-150$ & $3-4$ & $8-17$ & Пд \\
\hline 3 & $25-50$ & понад 4 & $17-35$ & $3 x$ \\
\hline 2 & $0,1-25$ & $1-2$ & $0,1-3$ & $\mathrm{Cx}$ \\
\hline 1 & понад 150 & $0,1-1$ & понад 35 & Пн \\
\hline
\end{tabular}

Таблиця 4. Функціональна рекреаційна оцінка рельєфу Дністровського РЛП

Table 4. Functional recreational assessment of the relief of the Dnistrovskyi RLP

\begin{tabular}{|c|c|c|c|c|c|c|c|c|}
\hline \multirow{2}{*}{\multicolumn{3}{|c|}{$\begin{array}{c}\text { Функції рекреаційного } \\
\text { використання та морфометричні } \\
\text { характеристики рельєфу }\end{array}$}} & \multicolumn{6}{|c|}{ Геоморфологічні підрайони } \\
\hline & & & \multirow{2}{*}{ 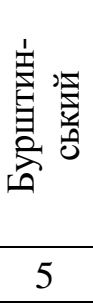 } & \multirow{2}{*}{ 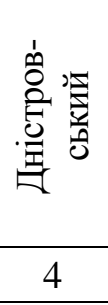 } & \multirow{2}{*}{ 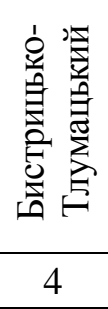 } & \multirow{2}{*}{ 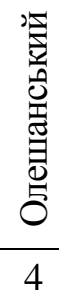 } & \multirow{2}{*}{ 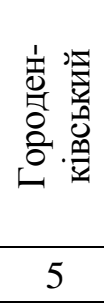 } & \multirow{2}{*}{ 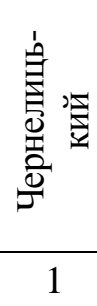 } \\
\hline \multirow{14}{*}{ 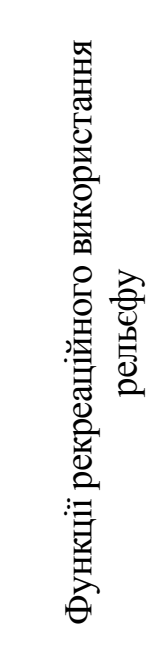 } & \multirow{5}{*}{ 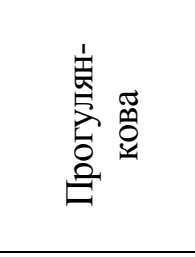 } & $\mathrm{BP} *$ & & & & & & \\
\hline & & ГР & 2 & 2 & 3 & 4 & 4 & 2 \\
\hline & & KC & 2 & 2 & 4 & 4 & 5 & 2 \\
\hline & & $\mathrm{EC}$ & 3,5 & 5 & 1,5 & 2 & 1,5 & 1,5 \\
\hline & & $\mathbf{C O}$ & 12,5 & 13 & 12,5 & 14 & 15,5 & 6,5 \\
\hline & \multirow{5}{*}{ 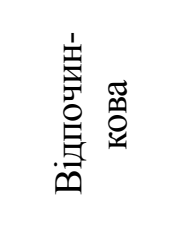 } & $\mathrm{BP}$ & 3 & 2 & 2 & 2 & 3 & 1 \\
\hline & & ГР & 4 & 4 & 1 & 2 & 2 & 4 \\
\hline & & KC & 5 & 5 & 3 & 3 & 4 & 5 \\
\hline & & $\mathrm{EC}$ & 3,5 & 5 & 1,5 & 2 & 1,5 & 1,5 \\
\hline & & $\mathrm{CO}$ & 15,5 & 16 & 7,5 & 9 & $\mathbf{1 0 , 5}$ & 11,5 \\
\hline & \multirow{4}{*}{ 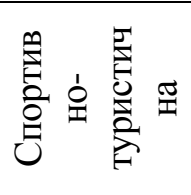 } & $\mathrm{BP}$ & 3 & 4 & 4 & 4 & 3 & 5 \\
\hline & & ГР & 2 & 2 & 5 & 4 & 4 & 2 \\
\hline & & $\mathrm{KC}$ & 1 & 1 & 3 & 3 & 2 & 1 \\
\hline & & $\mathrm{CO}$ & 6 & 7 & 12 & 11 & 9 & 8 \\
\hline
\end{tabular}

*Примітка. ВР - вертикальне розчленування, ГР - горизонтальне розчленування, КС - крутість схилів, ЕС - експозиція схилів, СО - сумарна оцінка.

*Note. ВP - vertical relief dissection, ГР - horizontal relief dissection, $\mathrm{KC}-$ slope, $\mathrm{CO}$ - total score. 

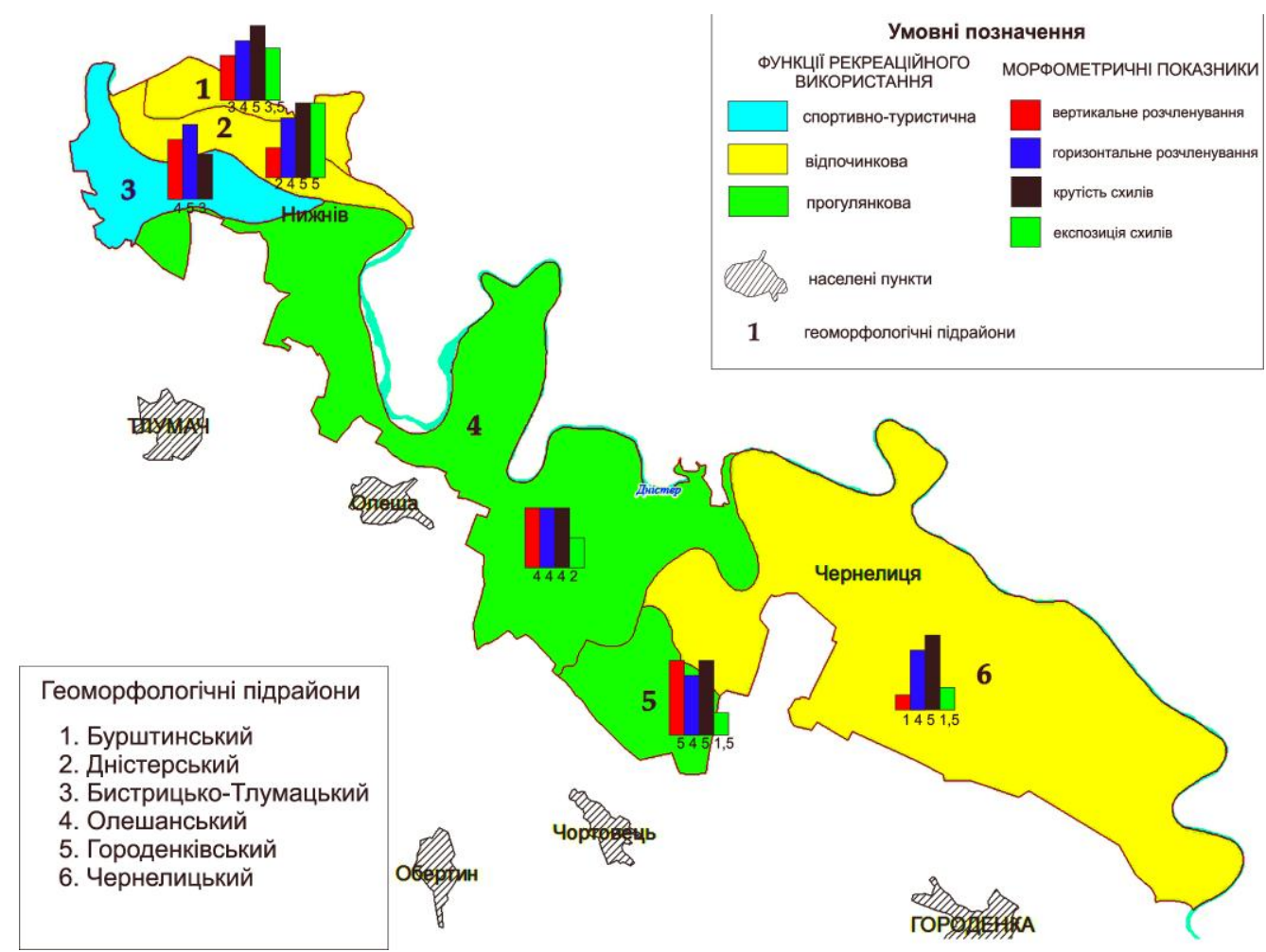

Рис. 5. Рекреаційна оцінка рельєфу Дністровського РЛП

Fig. 5. Recreational relief assessment of Dnistrovskyi RLP

Висновки. Завдяки виконаному дослідженню отримано такі результати:

1) найкращі умови для прогулянкового виду рекреації мають Городенківський та Олешанський геоморфологічні підрайони із найвищою сумарною оцінкою 15,5 та 14 балів відповідно, а доволі несприятливі - Чернелицький підрайон (6,5 балів);

2) відпочинковій функції найбільше відповідає Бурштинський підрайон (15,5 балів) та Дністерський (16 балів) - завдяки незначній розчленованості і рівнинності рельєфу. Найнесприятливіші умови для відпочинку визначено в Олешанському підрайоні, де сумарна оцінка придатності рельєфу цій функції становить 9 балів;

3) для спортивно-туристичного використання найпридатніший рельєф у Бистрицько-Тлумацького підрайону, який набрав 12 балів. Завдяки значним перевищення висот, мальовничим скелям і уступам ці території є цікавими для розвитку скелелазіння і парапланеризму, а наявність карстових печер відкриває перспективи для розвитку спелеотуризму.

Зазначимо, що для розвитку відповідних видів рекреаційної діяльності важливою є наявність об'єктів живої і неживої природи, природних атракцій та специфічних геолого-геоморфологічних умов для розвитку спелеотуризму, планеризму, альпінізму тощо. Важливою також $\epsilon$ оглядовість території i контрастність краєвидів. Цьому сприяє наявність “відкритих" вершин і оглядових точок. Останні слід використати при проектуванні туристичних маршрутів, оскільки 3 них відкривається панорамний огляд як каньйону Дністра, так i краєвидів Покутської височини. 


\section{СПИСОК ВИКОРИСТАНОЇ ЛІТЕРАТУРИ}

Андрейчук Ю. ГІС в екологічних дослідженнях та природоохоронній справі / Ю. Андрейчук, Т. Ямелинець. - Львів : Простір-М, 2015. - 284 с.

Атлас Івано-Франківської області / За ред. О. І. Шаблія. - Київ : ДНВ “Картографія”, 1989. -32 c.

Байрак Г. Висвітлення морфометричних показників рельєфу методами ArcGIS / Г. Байрак // Проблеми геоморфології і палеогеографії Українських Карпат і прилеглих територій: Збірник наук. праць. - Львів : ВЦ ЛНУ ім. І. Франка, 2008. - С. 135-140.

Байрак Г. Методичні прийоми визначення та відображення густоти розчленування рельєфу у середовищі ArcGIS / Г. Байрак // Фізична географія та геоморфологія. Вип.58. - Київ : Обрії, 2010. - С. 137-143.

Бредихин А. В. Рекреационно-геоморфологические системы / А. В. Бредихин. Смоленск : Ойкумена, 2010. -328 с.

Геренчук К. І. Природа Івано-Франківської області / К. І. Геренчук. - Київ : Вища школа, 1973. - $160 \mathrm{c.}$

Горішний П. М. Морфологічний аналіз рельєфу для інженерних потреб (на прикладі Західного Поділля) : автореф. дис. на здобуття наук. ступеня канд. геогр. наук / Горішний Павло Михайлович - Львів, 1998. - 19 с.

Горішній П. Рекреаційна оцінка рельєфу пропонованого Розтоцького національного парку / П. Горішний, Ю. Зінько, М. Кобелька // Вісн. Львів. ун-ту. Серія геогр. 1994. - Вип. 19. - С. 12-18.

Загрійчук В. Аналіз морфометрії рельєфу Тлумацького району Івано-Франківської області засобами ГІС / В. Ф. Загрійчук // Матеріали XVII студентської наукової конференції "Реалії, проблеми та перспективи географії в Україні" (18 травня 2016 р). - Львів : ВЦ ЛНУ ім. Івана Франка, 2016. - С. 37-45.

Загрійчук В. Рекреаційна оцінка рельєфу Дністровського регіонального ландшафтного парку / В. Ф. Загрійчук // Матеріали XIX студентської наукової конференції "Реалії, проблеми та перспективи географії в Україні" (16 травня 2018 р). - Львів : ВЦ ЛНУ ім.. Івана Франка, 2018. - С. 114-121.

Звіт про виконання договірної теми “Збір, систематизація та узагальнення матеріалів для розроблення проекту організації території Дністровського регіонального ландшафтного парку” під керівництвом Марискевич О. Г., фондові матеріали Інституту екології Карпат НАН України. - Львів, 2012. - 72 с.

Зінько Ю. В. Рекреаційна оцінка рельєфу та його трансформація в Українських Карпатах / Ю. В. Зінько, І. С. Гнатяк // Сучасні проблеми і тенденції розвитку географічної науки: Матеріали міжн. конф. до 120 річчя географії у Львів. унTi. -2003 . - C. 241-243.

Карпенко Н. І. Інженерний аналіз рельєфу рівнинних територій для потреб рекреаційного використання / Н. І. Карпенко // Геоморфологічні дослідження в Україні: минуле, сучасне, майбутнє. - 2002. - С. 136-138.

Карпенко Н. Методичні рекомендації до курсу "Рекреаційна оцінка рельєфу" / Н. Карпенко, П. Горішний, Ю. Зінько, - Львів : ВЦ ЛНУ ім. Івана Франка, 2005. $-46 \mathrm{c}$.

Кравчук Я. С. Геоморфологічне картографування: навч. посібн. / Я. С. Кравчук Львів : ВЦ ЛНУ ім. Івана Франка, 2006. - 30 с. 
Марчак А. Методика морфометричного аналізу рельєфу басейнових систем гірських територій засобами ГІС-технологій (на прикладі бассейну р. Прут у межах Чорногори / А. Марчак // Вісн. Львів. ун-ту. Серія геогр. - 2012. №40, Ч. 2. - С. 68-90.

Національний атлас України / Під ред. Л. Г. Руденка. - Київ : ДНВП “Картографія”, 2007. $-435 \mathrm{c}$.

Тишков X. Методы за анализ и оценка на рекреационите ресурси / Х. Тишков. София, 1984.

Pereira P. Methodological guidelines for geomorphosite assessment / Pereira P., Pereira D. // Geomorphologie: relief, processus, environnement. - № 16. - 2010. pp. 215-222.

Serrano E. Assessment of geomorphosites in natural protected areas: the Picos de Europa National Park (Spain) / Serrano E., Gonzalez-Trueba J. J. // Geomorphologie: relief, processus, environnement. - № 3. - 2005. - pp. 197-208.

\section{REFERENCES}

Andreychuk, Yu., Yamelynets, T. (2015) GIS v ekolohichnykh doslidzhenniakh ta pryrodookhoronnii spravi [GIS in environmental research and environmental affairs]. Lviv: Prostir-M, 284 (In Ukrainian).

Bayrak, G. (2008). Vysvitlennia morfometrychnykh pokaznykiv reliefu metodamy ArcGIS [Illumination of morphometric indices of relief by ArcGIS methods]. In Problemy heomorfolohii i paleoheohrafii Ukrainskykh Karpat i prylehlykh terytorii: Zbirnyk nauk. prats. Lviv, 135-140 (In Ukrainian).

Bayrak, G. (2010). Metodychni pryiomy vyznachennia ta vidobrazhennia hustoty rozchlenuvannia reliefu u seredovyshchi ArcGIS [Techniques identify and display density dismemberment of relief among ArcGIS]. In Fizychna heohrafiia ta heomorfolohiia, 58, Kyiv, 137-143 (In Ukrainian).

Bredikhin, A. V. (2010). Rekreatsyonno-heomorfolohycheskye systemy [Recreationalgeomorphological systems], Smolensk: Oikumen, 328 (In Russian).

Herenchuk, K. (1973). Pryroda Ivano-Frankivskoi oblasti. [The nature of the IvanoFrankivsk region]. Kyiv, 160 (In Ukrainian).

Horishnyi, P. M. (1998). Morfolohichnyi analiz reliefu dlia inzhenernykh potreb (na prykladi Zakhidnoho Podillia) [Morphological analysis of relief for engineering purposes (in the example of Western Podillya)] : avtoref. dys. na zdobuttia nauk. stupenia kand. heohr. nauk . Lviv, 19 (In Ukrainian)

Horishnyi, P., Zinko, Yu., Kobelka, M. (1994). Rekreatsiina otsinka reliefu proponovanoho Roztotskoho natsionalnoho parku [Recreational assessment of the relief of the proposed Roztocka National Park]. In Visnyk of the Lviv University. Seriya Geografichna, 19, 12-18 (In Ukrainian).

Karpenko, N. I. (2002). Inzhenernyi analiz reliefu rivnynnykh terytorii dlia potreb rekreatsiinoho vykorystannia [Engineering analysis of the relief of flat territories for the needs of recreational use]. In Geomorphological studies in Ukraine: past, present, future, 136-138 (In Ukrainian).

Karpenko, N., Horyshnyi, P., Zinko, Yu. (2005). Metodychni rekomendatsii do kursu "Rekreatsiina otsinka reliefu" [Methodical recommendations for the course "Recreational assessment of the relief]. Lviv, 46 (In Ukrainian). 
Kravchuk, Ya. (2006). Heomorfolohichne kartohrafuvannia. [Geomorphological mapping: Manual]. Lviv, 30 (In Ukrainian).

Marchak, A. (2012). Metodyka morfometrychnoho analizu reliefu baseinovykh system hirskykh terytorii zasobamy HIS-tekhnolohii (na prykladi basseinu r. Prut u mezhakh Chornohory. [Methods of morphometric analysis of the relief of basin systems of mountain territories by means of GIS technologies (on the example of the Prut River basin within the limits of Chornogora]. In Visnyk of the Lviv University. Seriya Geografichna, 40, Part 2, 68-90 (In Ukrainian).

Pereira, P., Pereira, D. (2010). Methodological guidelines for geomorphosite assessment. In Geomorphologie: relief, processus, environnement, 16, 215-222.

Report on the implementation of the contractual theme "Collection, systematization and synthesis of materials for the development of a project for the organization of the territory of the Dniester regional landscape park" under the direction of Maryskevich O.G., stock materials of the Institute of Ecology of the Carpathians of the National Academy of Sciences of Ukraine, Lviv, 2012, 72 (In Ukrainian).

Rudenko, L. (Ed.) (2007). Natsionalnyy Atlas Ukrainy [National Atlas of Ukraine]. Kyiv, SSPE "Cartography”, 435 (In Ukrainian).

Serrano, E., Gonzalez-Trueba, J. J. (2005). Assessment of geomorphosites in natural protected areas: the Picos de Europa National Park (Spain). In Geomorphologie: relief, processus, environnement, 3, 197-208.

Shabliy, O. (Ed.) (1989). Atlas Ivano-Frankivs koi oblasti [Atlas of Ivano-Frankivsk oblast], 32 (In Ukrainian).

Tishkov, H. (1984). Metody za analyz y otsenka na rekreatsyonyte resursy [Methods for analysis and evaluation of recreational resources], Sofia (In Bulgarian).

Zahriichuk, V. (2016). Analiz morfometrii reliefu Tlumatskoho raionu Ivano-Frankivskoi oblasti zasobamy GIS [Analysis of the morphometry of the relief of the Tlumach district of the Ivano-Frankivsk region by means of GIS]. In "Realities, Problems and Prospects of Geography in Ukraine": Materials of the XVII Student Scientific Conference (May 18, 2016), Lviv: VC Ivan Franko National University of Lviv, 3745 (In Ukrainian).

Zahriichuk, V. (2018). Rekreatsiina otsinka reliefu Dnistrovskoho rehionalnoho landshaftnoho parku [Recreational assessment of the relief of the Dniestrovskiy Regional Landscape Park] In "Realities, Problems and Prospects of Geography in Ukraine": Materials of the XIX Student Scientific Conference (16 May 2018), Lviv: VC Ivan Franko National University of Lviv, 114-121 (In Ukrainian).

Zinko, Yu. V. (2003). Rekreatsiina otsinka reliefu ta yoho transformatsiia v Ukrainskykh Karpatakh [Recreational assessment of relief and its transformation in the Ukrainian Carpathians]. In Modern problems and trends in the development of geographical science: Materials intern. conf., 241-243 (In Ukrainian). 